\title{
Palestinian children: a transformation of national identity in the Abbas era
}

\author{
JANETTE HABASHI
}

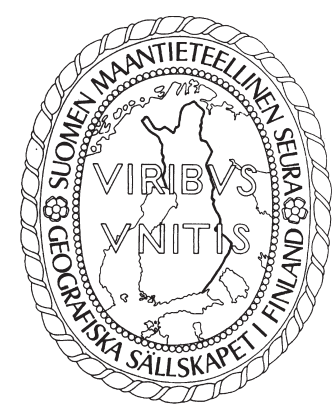

Habashi, J. (2019) Palestinian children: a transformation of national identity in the Abbas era. Fennia 197(1) 77-93. https://doi.org/10.11143/ fennia.71009

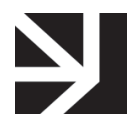

The constant rendering of Palestinian national identity provides crucial insight not only to the current Palestinian community's political status, but also to past and the future experiences. National identity echoes the intersectionality of history and local politics. For the last few decades, Palestinian national identity has been evolving with continuous alteration that encompasses local political discourse in the Palestinian community. Whereas it once embraced unity among different political ideologies, a shift occurred with Hamas election victory in 2006, which resulted in the division of the Palestinian community, whereby the Palestinian Authority, under Abbas leadership is ruling the West Bank, and Hamas is governing the Gaza Strip. This political tension has served to render national identity. Palestinian children echoed such politics in the construction of their national identity through their interpretation of personal experiences that are intertwined with current political events. Therefore, the purpose of this paper is to show how Palestinian children articulated national identity in a post-Arafat/Abbas era, recognizing that national identity is not static.

Keywords: Palestine, national identity, children, youth

Janette Habashi, Department of Human Relations, The University of Oklahoma, 601 Elm Avenue, Norman, OK 73019 USA. E-mail: jhabashi@ou.edu

\section{National identity: the Palestine case}

National identity serves to unite communities within nation-states, as it provides a sense of belonging and connection among people, despite never knowing, or meeting each other. This creates an imagined bond among diverse members of society (Anderson 2006). National identity is an inherent function in nation-states, especially as society shifted from tribal cultures to a modernity structure that organized societal power and governmental bureaucracy (Venn \& Featherstone 2006). Therefore, society engaged in a multi-dimensional identity that encapsulated an ethnicity dimension, but also included a collective narrative involving aspects of history, common rights and duties, mass culture and others. The development of a multi-dimensional national identity is interactive with local political circumstances. In Palestine for example, national identity shifted with the local political reality, and emerged alongside the concept of nationalism that spread throughout Europe in the $20^{\text {th }}$ century, as anti-Semitism fueled Zionism and the quest for a Jewish homeland (Tyler 2011). Global politics of the $20^{\text {th }}$ century shaped the colonization of Palestine, aiding in the formation of a unique national identity that is embedded in collective and individual accounts of oppression and expulsion. Such narratives of colonization did not dissipate but were reconstructed according to different local political realities. 
National identity is not static, it evolves with continuous reconstruction. This constant rendering can be observed in Palestinian national identity, as it provides insight into local politics throughout different eras, as well as to the reconstruction of national narratives. The formation of national identity is not exclusive to adults; on the contrary, children are active in the construction of national identity through their interpretation of local politics. Contemporary politics create nuances in children's national identity and distinguish it from one generation to another. Focusing on a specific political era shows the impact of politics as they relate to children's construction of national identity. Politics have shaped the views of what it means to be Palestinian.

The purpose of this research is to examine the construction of Palestinian children's national identity, as it relates to their own political experiences under the leadership of Mahmoud Abbas, supporting the notion that national identity is not static. To understand this interaction, it is crucial to provide an overview of Palestinian politics and its impact on children's formation of national identity. Following this discussion, a methodology and data analysis is provided regarding the collection of research on Palestinian children's national identity, transitioning into a thorough examination of two categories that emerge: Abbas era self and Abbas era other, as well as nuances within each category.

\section{The impact of history on national identity}

Palestine as a nation-state is constantly disputed due to its different manifestations throughout history. In 1948, Palestinians experienced Al-Nakba, the forceful displacement of $70 \%$ of its population by the Zionist army, which resulted in the creation of the Israeli State (Beinin \& Hajjar 2014). Still, the Palestinian atrocities continued; in 1967, Palestinians experienced Al-Naksa, the Israeli invasion of the West Bank and Gaza Strip, which resulted in the ongoing Israeli military occupation of these territories, leading to the displacement of more than one third of the Palestinian population (Nassar 1997). Throughout both Al-Nakba and Al- Naksa, Palestinians were forced to settle in various refugee camps in Lebanon, Jordan, Syria, Egypt and other Arab countries and are still unable to return to their homes today. These two major political events drew the 1967 Palestinian borders within the international community, whereby Palestine lost $77 \%$ of its original land (Beinin \& Hajjar 2014). National identity within the Al-Nakba era captured experiences of Zionist colonization, collective expulsions and international betrayal. More importantly, it centered on pan-Arab ideology for the liberation of Palestine which consequently failed. This is contrary to the Palestinian national identity during the AlNaksa era, though it was associated with the same sentiments of oppression and goals for liberation, as the establishment of the Palestinian Liberation Organization (PLO) in 1964 emphasized that the liberation of Palestine would achieve Arab unity, contrary to the initial phase of national identity. Upon the formation of the PLO, Palestinian people explicitly expressed their national identity by aligning with one of its seven political parties. Fatah was the most popular political party within the PLO, as it engaged with all sectors of society and diaspora. During this time, secularism was a staple of Palestinian national identity. Another major shift occurred in the late 1980s with the formation of the Hamas party, which called for embracing and proclaiming Islam as a major aspect of Palestinian national identity. Within the first Intifada era, religion as a part of national identity was profoundly expressed and manifested in local politics, as Hamas remained the only political party in Palestine that did not join the PLO, due partially to ideological differences regarding secularism in Palestinian society, and largely to its perception on the existence of an Israeli state (Tuastad 2013). The integration of religion into local politics contributed to the contemporary expression of Palestinian national identity, as well as to the tension in reaching a consensus regarding a political agreement with Israel.

After the first Intifada (1987-1991), the PLO's formal recognition of Israel as a state, in congruence with a Palestinian statehood (Kaufman 2011) marked the first talks of peace between Israel and Palestine. The Oslo Accords of 1993 detailed a plan for Israel to withdraw from the Occupied Territories, reverting back to the 1967 borders of Palestine, however, this was unsuccessful due to the continuing expansion of Israeli settlements within the Occupied Territories, rather than withdrawal of Israeli forces (Shafir 2007). Hamas at the time rejected the Oslo Accords and its implication of establishing the Palestinian Authority (Hilal 2010). The second Intifada (2000-2005) erupted due to the continuous harsh conditions imposed by Israel within the Occupied Territories. During this time, 
Hamas engaged in resistance, but also feared that Fatah may cost Palestinian's their birthright (Tuastad 2013). Though the difference between the PLO (Fatah) and Hamas is based on ideology, both continued to strive for the same goal. However, the breaking point came following the death of the Palestinian Authority (PA) president, Fatah leader Yasser Arafat in 2004. In 2006, the occupied territory (the Gaza Strip and West Bank) held a democratic election, which ultimately led to the split between Hamas and Fatah. The surprising Hamas electoral victory resulted in Fatah's attempt to deprive Hamas of governance by utilizing political and military power (Dabed 2010), signaling the beginning of an era discussed in this manuscript as the Abbas era. For a few months, the disagreement between Hamas and Fatah resulted in violent confrontations between members of each party (Ghanem 2013). The refusal of Fatah to allow Hamas to rule resulted in the Gaza Strip falling under Hamas control, and the West Bank under Fatah control, presenting a major division amongst Palestinian people, thus complicating the goal of attaining Palestinian statehood. The continuous alteration of local political realities impacted Palestinian national identity, and contributed to defining Palestinian children's national identity within a specific era.

\section{Premises of children's Palestinian national identity}

Children's construction of national identity is greatly impacted by local politics. Children are not unaware of local politics, on the contrary, they are active responders, as local politics impact their family, and community (Habashi 2013). Israeli occupation is expressed throughout the Palestinian narrative, as it determines children's everyday realities of education, health care, free movement, future and wellbeing. Therefore, Palestinian children's responses are continuously reshaped, while constructing both the self and other within national identity. The self can be described as "the way a person experiences himself as himself" (Gilhotra 1995, 599), while the concept of other stems from "difference', which matters because "it is essential to meaning: without it meaning could not exist" (Hall 1997 , 234). For Palestinians, the concept of 'self' is embedded in the perception of what it means to be a Palestinian, whereas the 'other' tends to be associated with oppression and Israel. Thus, the concept of both self and other play a crucial role in children's construction of national identity, as both are contextualized within local politics.

Palestinian children's contemporary national identity is founded on the construction of the self and other that is connected to the national experience of colonization and Zionism, as discussed in my previous work (Habashi 2005), in which Palestinian children constructed the self and other within their own interpretations of the historical, collective narrative and political discourse. Indeed, the historical narrative has not changed. However, local politics have changed drastically, following the establishment of the Palestinian Authority under the leadership of Abbas, a Fatah leader, which has impacted the current generation of Palestinian children's construction of national identity.

Hopkins and Pain (2007) argued that children's construction of social identity is not only associated with personal experience and intersectionality, but with generational eras that are contextualized by local reality and politics. Therefore, this manuscript provides a discussion of Palestinian children's construction of self and other, which are contextualized within Abbas era politics, as most participants in this study have solely experienced Abbas leadership and the establishment of the Palestinian Authority. Although Palestinian politics did not drastically shift following the death of Arafat, the two had differing leadership styles. Arafat was seen as a strong leader who championed various forms of resistance (Kurtzer 2017), while Abbas chose to cooperate with the demands of the Israeli government, and struggled to rule his own people (Jarbawi \& Pearlman 2007). Under Abbas' control, the Palestinian Authority also began to work more closely with the Israeli government on multiple levels, thus, transforming the Palestinian collective narrative by means of altering relations with Israel in terms of resistance and reactions to occupation. On many occasions, the PA attempted to control local resistance and opposition against Israeli occupation and settlement expansion (Tartir 2017).

The Abbas leadership and its interactions with Israel has had a continual impact on Palestinian's everyday lives. One example of such political reality that should have been altered twenty years after the Oslo agreement is the continuation of dividing the West Bank into three areas (A, B and C). Area A is under the control of Palestinian authority, area B is under the joint control of Israel and Palestine, 
and area $\mathrm{C}$ is under the control of the Israeli military. The premise being that these areas will form one cohesive geographic entity known as a Palestinian state. However, this division of the West Bank did not disappear after the Oslo agreement, on the contrary, Israel continues its practices of occupation and settlement expansion. Furthermore, this division mounted additional separation that corresponds with national ID cards and discrimination practices, whereby Palestinians living in Jerusalem have blue ID's, which provide them with Israeli resident rights and allow them to visit the West Bank. An orange ID is associated with Palestinians in the West Bank who have limited movement. And a green ID is for Palestinians living in the Gaza Strip who have no free movement but are rather living behind walls in an open jail (Tawil-Souri 2012). These Israeli political conditions, in addition to confiscation of land, control of education, health care and freedom are the daily reality of the Palestinian community (Giacaman et al. 2009). The generations involved in this study are merely experiencing Israeli occupation under the auspices of Abbas leadership of the Palestinian authority. The aftermath of a Hamas electoral victory and the PA's resistance to allow Hamas to legitimately govern resulted in the split of the West Bank and Gaza Strip. This split is central within the narratives of the current generation, as it is deeply inherit in local politics and the meaning of national identity. Therefore, children's construction of self and other is framed within a crucial period of local politics that redefine national identity.

\section{Methodology}

The present research is based on a data segment of a longitudinal study that took place from 2007 to 2011, with children aged 12-15 years old, from cities, villages, and refugee camps in the West Bank, which produced a comprehensive analysis of youth political socialization. All participants attended either middle school or high school in the West Bank at the time of data collection. Though participants were children when their participation began, some are referred to as youth due to the fact that they aged throughout the duration of the study. This study utilized snowball sampling in order to recruit a total of 15-30 youth participants throughout the duration of the study, with a mixture of females and males. These participants were from cities, villages and refugee camps throughout the West Bank and their political activity greatly varied. Upon identifying a small initial group of participants, children then encouraged other members of their peer groups and communities to join. Additionally, adult community leaders encouraged children's involvement in the study because it would serve to improve their learning experiences in school and community. The participation of children was without incentive or non-governmental organizations oversight. Participation of the children fluctuated, as some made personal decisions to withdraw from the study, and others opted in.

The participants were asked to document their everyday lives by journaling about daily routines and local social and political issues, as well as their reactions. Children were first asked to write twice a week with guidelines that included questions such as what are your views on what is happening in your current community, and, describe your daily routine and what sort of issues may disrupt this routine. After some time, the participants wanted to write more about what their lives were like, without much emphasis on the guidelines. Thus, the participants took ownership over the project and were able to focus on their thoughts on being a member of the Palestinian community. This approach provided insight as to how children frame their perspectives without the control of adult perceptions or preconceived notions. The participant ownership of the research challenged the top-down model of children understanding local events (Habashi 2017). This is significant in comprehending children's construction of national identity.

To capture children's perspectives, each journal was translated by a local bilingual translator from Arabic to English to maintain the cultural context of the writing. After translation, in order to minimize bias, it was necessary for two researchers to read and code the data independently and validate the interpretation of children's construction of national identity. Cross-referencing served to verify the coding structure and the relationship between the codes, as well as generated patterns of the themes (Self and Other). Grounded theory guided the analysis of the research. The significance of grounded theory lies in making meaning of the themes and relationships embedded throughout the data. The analysis focused on the perspectives of participants, as this provided a spectrum of views on the two themes. Each theme produced several dimensions that included fragmentation, whereby insight was 
provided regarding how children's national identity changed over time, though it also maintained some consistency with existing research (Habashi 2008). In the present study, Palestinian children emphasized seven dimensions of the self and five dimensions of the other, which are framed within Abbas era political discourse.

\section{Theme one: the self}

The self in national identity is relative to how one perceives and experiences him/herself as a part of a community. Within this theme, Palestinian children articulated the self in seven dimensions and referenced them within the political era of Abbas leadership. The seven dimensions of the self are: (1) Abbas era historical refugee self, (2) Abbas era ennobled self, (3) Abbas era traitor self, (4) Abbas era religious self, (5) Abbas era resistance self, (6) Abbas era geographic self, and (7) Abbas era expressive self.

\section{Abbas era historical refugee self}

Historical devastation is not negated by current politics or political figures, but is continuous throughout the lives of all Palestinians. Children expressed national identity in this dimension by addressing the history of the Palestinian people and their forced displacement in relation to their current political status' as refugees. Their historical narratives centered on Al- Nakba, the 1948 expulsion of more than two thirds of Palestinians by Zionist militants, and on Al-Naksa in 1967, when Israel invaded the West Bank and Gaza Strip, expelling between 300,000 to 400,000 Palestinians (Kattan 2005). The experiences of 1967 are still being depicted within some of the participant's homes, as one female from Hebron wrote, "I asked my father about that, he was 18 years old at that time, he said: Israeli forces entered our city on 6/6/1967, they expelled many people". The 1967 war played an important role in this dimension of the self, as many participants are third and fourth generation refugees, thus, it is a dominant part of their daily lives. This dimension is not confined to one generation, as I have found in my previous research, Palestinian children from three generations who identified as refugees, acknowledged their current living situation in the West Bank, but also recognized they have roots stemming from a specific village prior to the Zionist expulsion Habashi (2013). One female from Nablus stated,

They call us displaced people, and sometimes they call us refugees, all this as a result for what happened in 1948 and 1967. Unfortunately, we didn't return, but still we have hope. We will return from Lebanon, Syria, and Jordan. And we will fight and serve our home land.

Such historical experiences have become part of the participants daily reality, and are reinforced when Israeli leadership, such as Prime Minister Benjamin Netanyahu, consistently denies the Palestinian right of return, which is guaranteed by United Nations Resolution 194. One female from Hebron shared insight by stating,

Netanyahu's racist speech denies the Palestinian legitimate rights to establish a sovereign state. Also it denies Jerusalem to be the capital of Palestine, yet asks the Palestinians to recognize a Jewish state. It seems he has the right to expel indigenous people living in the borders of 1948 under the pretext of a Jewish State. Furthermore, he denies the Refugees right of return which is guaranteed by the international law and UN resolutions.

Israel's failure to acknowledge the Palestinian right of return is in clear violation of international law, in that it places a burden on neighboring States that must provide refuge for wrongfully expelled people (Kattan 2005). Throughout the Abbas era, the Right of Return is discussed in relation to Palestinians returning to 1967 borders, rather than to specific towns or villages prior to the establishment of Israel (Schenker 2008). This alternative interpretation of an international law reshapes the future meaning of being a refugee, while undermining the rights of Palestinian people. Abbas has contributed to denying the Palestinian people, as well as coming generations, their right to return, thus creating the Abbas era historical refugee self. Abbas is the first Palestinian leader to reframe the Palestinian right of return, meaning that Al-Nakba descendants will not have the right to 
return to their homes of 1948, but can return to the West Bank (Tadros 2017). This perspective not only limits Palestinian rights, but also the alters the meaning of the future historical self.

\section{Abbas era ennobled self}

Being proud to be Palestinian is one quality found in the self. Many participants articulated and expressed aspects of the ennobled self in terms of Palestinian culture, traditions, national aspirations and roots of their ancestors. For the participants, one prominent characteristic of national identity is the pride of country, and leadership. During and after his leadership, Arafat was seen as an icon of national pride, as one female participant states,

Today was the fourth anniversary of Abu Ammar (Arafat) martyrdom... All the schools did a ceremony and sang the national anthem. Our song was about stop the siege, occupation, Judaization, and assassination. Downtown was closed because boys were throwing stones on the soldiers, and soldiers threw tear gas and bullets. The radio had national songs the whole day. This day was beautiful and represented how we love Palestine. Abu Ammar was dead because of Palestine and we fight for his dream to free Palestine. His spirit will remain for the upcoming generations.

Arafat was perceived as a dedicated Palestinian leader, as opposed to Abbas who must consistently convince Palestinians that he is a legitimate leader rather than someone chosen by the Americans to replace Arafat (Jarbawi \& Pearlman 2007). Although this disconnect did not cause the participants to be less proud of being a Palestinian, as they are acutely aware of the role that ever-changing politics play in their everyday lives, as one female from Hebron wrote "In my journaling all the subjects are political and national. This is the Palestinian child and we will be always like this until our land becomes free, our cause takes our minds and hearts." Farsakh (2011) explains that the Palestinian 'cause' can be traced to when refugees took matters into their own hands and began fighting for Palestinian statehood and return.

The participants expressed national pride through various symbols associated with liberation and history, especially the Palestinian flag, which was derived from the Arab Revolt (1916-1918), "signifying the need for an all-Arab effort against the Zionist cause", as well as adding "legitimacy to their struggle" (Podeh 2011, 435). The flag as a symbol of pride can be observed throughout history, as the Palestinian Declaration of Independence, adopted in Algierson November 15, 1988 stated "We call upon our great people to rally to the Palestinian flag, to take pride in it and to defend it so that it shall remain forever a symbol of our freedom and dignity in a homeland that shall be forever free". The flag is mentioned often throughout the participant's journals, as a male from Qalqilya discussed Jerusalem and how the flag would represent liberation, nobility, and the right to exist for the Palestinian people:

It is an Arab city and it's the capital of Palestine, soon it will be free, and one of the Palestinian girls or boys will raise the Palestinian flag on the dome of the rock to announce that Jerusalem is for us. It was for us and it is for us until the Day of Resurrection comes.

Being a proud Palestinian involves the sentiment of fighting for liberation, rights, culture and symbols. However, within the Abbas era, pride in Palestinian leadership was excluded, as this leadership has not captured the notion of fighting for the Palestinian rights. Abbas is not perceived as acting on behalf of Palestinians interest but rather an agent who is concerned with coordinating security with Israel (Hamdi 2018).

\section{Abbas era traitor self}

Traditionally, traitor informatives have been associated with individual acts. I have found this to be the case in my previous work, whereby, Palestinian children associated the traitor self to collaborators who served the Israeli government and hindered the liberation of Palestine (Habashi 2005). Within the Abbas era, children have transformed the meaning of the traitor self, in that it is no longer just an individual act, but is associated with Palestinian leadership betrayal. As one female participant discussed their dissatisfaction with Abbas, especially regarding the division of Jerusalem, 
I read a flash news about our President Mahmoud Abbas, he said that Jerusalem will be divided into two parts. This was the agreement between the President and Israel, but we refuse this. Jerusalem belongs to us. We will not accept this. Israel starts to demolish houses, and expels people in Jerusalem. Where is the President to stop all that, and resolve the split?

The frustration with President Abbas and the lack of standing up to Israel is echoed in another female participant's journal, "Mahmud Abbas didn't do anything for them I hate him". The discussion of dividing Jerusalem was not on the table during the Arafat era, as he was strongly against the division of Jerusalem (Baskin 2001), whereas Zelnick (2010) notes that Abbas met with former Israeli Prime Minister Ehud Olmert on 35 occasions to discuss "the division of sovereignty in Jerusalem" (ibid., 26). Despite the installment of the Palestinian Authority (PA) in 1994, which was meant to be a stepping stone for achieving a Palestinian state, Israel has continued its oppressive practices of land confiscation, assassinations, imprisonment of adults and children and expansion of settlements, all of which conflict with the Palestinian aspiration of statehood (Shafir 2007; Fields 2010). These actions supported the notion of perceiving the Palestinian leadership as part of the traitor self, as one male participant shared a community experience regarding the PA, "Last night the PA entered and arrested some youth from the camp... The reason for the arrest was it is better that the Israeli wouldn't arrest him. The youth were beaten and got hurt... the PA is not even hiding that they are working with Israeli government."

Zelnick (2010) discusses the security agreement between the PA and Israeli government, recognizing that the Israeli government and the Fatah party shared a common interest to contain Hamas, which resulted in "significant cooperation in such matters as intelligence, the apprehension of suspected terrorists, and the training and equipping of Palestinian security forces" (ibid., 24). The transition of the traitor self from the association of individual acts to include Palestinian leadership reflects the disconnect in the national narrative and the lack of trust between the leadership and the people, which did not exist prior to the Abbas era (Khouri 2018).

\section{Abbas era religious self}

Marshall $(2013,15)$ states, "cultural expressions of religion are central to children's political identities and articulation". Religion in Palestinian national identity is no longer only an expression of faith, but can be identified within local politics as it distinguishes between political parties (Hamas \& Fatah). This dimension became more complicated during Abbas era, as it evolved amongst a significant political divide in Palestine. The politicization of Islam is recognized throughout the participant's journals in relation to Israel and the PA. When Hamas took control of Gaza in 2007, it was declared that Islamic rule was there to stay, a strong opposition to its secular counterpart, Fatah, which was ruled by Abbas (Milton-Edwards 2008).

In the 1980s, the failure of secular political parties to liberate Palestine paved the way for the politicization of Islam, which manifested in the formation of Hamas (Tuastad 2013). Yet secularism and religion were not at the root of friction within the Palestinian political community during Arafat leadership (Løvlie 2014). It was not until the Hamas electoral victory of 2006 and the refusal of the PA to transfer the governance of the West Bank and the Gaza strip that politicization of Islam became a distinct element in Palestinian political discourse. The disagreement between the two parties became violent, and in 2007, Hamas began forcing loyal Fatah security forces in the Gaza strip to flee to the Fatah dominated West Bank, resulting in a Hamas takeover of Gaza, while the PA, under the leadership of Abbas, continued the governance of the West Bank (Milton-Edwards 2008).

The politicization of Islam within Palestinian politics is recognized throughout the children's journals in relation to Israel and the PA. One male participant expressed this sentiment in regards to Hamas and Fatah by stating, "The parties have effects on people because each person belongs to a different party, they affect the students too. In my opinion the Palestinians should go back and stick to the Islamic faith." The friction between Hamas and Fatah has impacted the unity of the Palestinian people, although Palestinian people recognized that the problem does not lie in religion as faith, but rather stems from the politicization of religion (Løvlie 2014). This was echoed by another male participant: "All people talked about politics because it seems we will have a civil war between the two parties Fatah and Hamas... In my perspective the civil war is not a solution, harmony is, and Islam too, they 
have to compromise with each other." Palestinians recognized the misuse of religion in Palestinian politics and the fact that fight between Hamas and Fatah will not lead to the liberation of Palestinian.

For Palestinian children, religion in a faith based sense serves as a form of cohesion, which allows them to maintain the belief that God is on the side of the Palestinian cause. As one female participant points out, "Those strong children believe in God's mercy, they know that they will liberate their land one day". Religion provides strength to continue fighting for the liberation. Within religion, the Palestinian people find the ability to survive oppression and injustice. This notion was reiterated by a female participant, "To Gaza people be patient, God is with you and you will win over this wild enemy who doesn't know human rights and doesn't have any feelings". Their faith serves as hope that someone will be more powerful than the oppressor. Islam as a religion serves as a pillar of strength for the Palestinian children and community (Habashi 2013). Hence, the split in Palestine between the leadership of the Gaza Strip and the West Bank is a breaking point in the history of Palestine. Though political opponents have always existed, each would strive for the same goal. This division is intensified under the Abbas leadership, as it seems religion is a point of friction rather than a tool for achieving unity.

\section{Abbas era resistance self}

Resistance has been a part of the Palestinian narrative for many generations. The Abbas era resistance self transformed significantly from the Arafat era, whereas "in exchange for Western and Israeli support to keep political and economic power in its hands, the new Abbas leadership agreed to renounce all forms of resistance, both armed and non-violent" (Dabed 2010, 81). Within this political reality, Palestinians had not only to suffer from oppression, injustice and colonization, but also had to redefine the right to resist due to leadership, while Israel expands settlements and achieves the goal of creating the Greater Israel (Shlaim 2009).Thus, regardless of Abbas' call to restrain from resistance, the Israeli government and illegal settlers continue oppressive practices, which young Palestinians are responding to with new methods of resistance (Elgindy2011; Habashi 2017).

Jewish settlers are an active part of oppression as they are represented and supported by the Israeli government, and some even hold "decision-making positions in the civil service and the Israeli armed forces" (Sasley \& Sucharov 2011). They are considered Israeli citizens despite residing in the Palestinian Occupied Territories. Settlers carry weapons and have the power to intervene in Palestinian communities within the West Bank, often with the support of the Israeli army and government. Fields (2010) discusses Israeli settlements and their impact on preventing the Palestinians to move freely across the West Bank by building walls and creating checkpoints. Palestinians are actively resisting actions of Jewish settlers, as a female participant indicated, "Yesterday, there was a Jewish settlers' demonstration to enter Al-Aqsa mosque but the Palestinian who live in Jerusalem prevented them. We will not allow this to happen... we will not allow them to enter it even if we will have another Intifada." The Al-Aqsa mosque in Jerusalem is a contested holy site for Abrahamic religions, and the Israeli government continues attempts to control the compound by banning people from entering the mosque (Omar 2017). Another female participant expressed the reason for resisting Israel, "There will be no peace with Israel because they took our land, they killed our brothers, they demolished our houses, they displaced our people, they orphaned our children, and practiced all types of violence on us. We don't want peace with them."

Another element that the participants reiterate throughout this dimension is that resistance is a part of who they are as Palestinians, as one female participant indicated, "I love my country even if I will die I will not give up. Defending the country brings me pride, dignity, and freedom." Palestinian children's discussion of the resistance self included inherent hindrances embedded within different forms of leadership and the fight between Fatah and Hamas, as a female participant observed, "Israelis attack us because they know we are not one, we are divided, if we are united we can fight and return back to Palestine". In several journal entries, children saw that the fight between these two political parties is an obstacle to resisting Israeli oppression as one female participant stated, "Many families were killed because of Israel and the split between Hamas and Fatah. I think what happened in Gaza is complicated. I wish to reunite between the two parties to expel the occupation". The split between Hamas and Fatah has affected the goal of attaining a Palestinian statehood throughout the 
Abbas era, by means of making Palestinians "incapable of responding to any initiative to settle the problem of the occupation or the Palestinian problem as a whole" (Ghanem 2013, 27). Palestinian children often discuss unity, despite the split, as a means of achieving liberation. The constraints by Abbas in regard to resistance, parallel with the fight between Fatah and Hamas for governance, offer insight to the lack of ability by the leadership to guide any national resistance. Elgindy (2011) argues that Palestinians are equally frustrated with the leadership, as well as Israel and predicted, "if Palestinians mobilize on an even larger scale in the future, they are as likely to direct their anger at their leaders as at Israel"(ibid., 109). Meanwhile, this did not deter the community from resisting Israeli occupation, rather, it galvanised grassroot activists not to rely on leadership for guidance, but to establish other methods such as Boycott, Divestment, and Sanctions (BDS) movements against Israeli products (Høigilt 2015).

\section{Abbas era geographic self}

The geographic self is not only associated with roots and land, but also is considered as a political marker. After the Hamas victory in the 2006 election and the subsequent denial to govern the West Bank and Gaza Strip, the PA with the help of Israel fought Hamas, mainly in Gaza Strip (Usher 2006). However, this does not imply that there was no presence of Hamas in the West Bank. On the contrary, some areas in the West Bank are considered to be strongly affiliated with Hamas. After 2007, Palestinian Authority Security Forces (PASF) began targeting individuals with Hamas affiliation that did not endorse the PA political agenda and attempted to criminalize resistance. Tartir (2017) provided an ethnographic study of two main refugee camps (Jenin and Balata), in which the PASC consistently worked to eliminate any resistance to Israel and its PA proxity. The association of location with political elements has several dimensions, which is especially apparent in organizing the West Bank into ghettos (Baumgarten 2005) Prior to the Abbas era, Arafat had overwhelmingly advocated for the withdrawal of Israeli forces from the territories seized in 1967 (Slater 2001), with the anticipation that it would manifest in the creation of Palestinian state. This agreement provided a blueprint to divide the West Bank into three areas, known as Areas A, B, and C; Area A is made up 17\% of the West Bank and consists mostly of Palestinian towns and was to be governed by the Palestinian Authority; Area $B$ consists of many refugee camps and makes up $24 \%$ of land in which the Palestinian Authority is supposed to have civilian control, while Israel maintains control of security; and Area C, which is 59\% of West Bank land, is comprised of Palestinian civilians, as well as Israeli settlements and Israeli military bases, and was to remain under Israeli civilian and military control until all the three areas came under the sovereignty of a Palestinian state (Shafir 2007). This division was to span over a fiveyear period and result in the complete withdrawal of Israeli forces, the occupation remains today. Despite the fragmentation of a geographic location, the participants had a shared understanding that they maintain roots in the West Bank, the Gaza Strip, pre-1948 Palestine and diaspora, regardless of border alterations due to colonization and oppression.

The Israeli government attempts to control the Palestinian geographic location in various ways, including enforcing the use of colorized, identification cards meant to distinguish Palestinians from Israeli citizens, as Palestinians living in the West Bank do not have the same political status, or ability to travel as Palestinians living in Jerusalem (Tawil-Souri 2012). The children's journal entries indicated that some aspects of contemporary borders restrict their movement and hinder their way of life. For example, the Apartheid wall around the West Bank is discussed as an attempt to enclose the Palestinian community (Fields 2010). One female participant shared knowledge regarding the wall, "They walked on an unpaved road because the main roads were closed. Many adults were tying ropes to climb the wall, but they couldn't because Israeli soldiers monitor it, and placed barbed wires to defend the wall." Israel attributes the construction of the wall as being necessary for security purposes, however, Dolphin and Usher (2006) argue that it is being constructed to aid settlers' political interests, and notes that it is an attempt for Israel to gain more land by means of altering the green line borders.

Aside from the wall, Israel is creating other barriers to prohibit Palestinians to travel freely within the Occupied Territories. For example, the old city of Hebron in the West Bank is divided into two 
sectors, one governed by the PA (H1), and the other by the Israeli military ( $\mathrm{H} 2)$. Settlers living in $\mathrm{H} 2$ have no limitation on expanding their settlements, additionally, there are many security measures in place to protect these settlements, thus restricting the movement of Palestinians within $\mathrm{H} 2$ (Andoni 1997). A female participant discusses her experience in this area,

Today we went with the summer camp to Tomb of the Patriarchs (mosque), to the old city of Hebron. We walked $3 \mathrm{~km}$ to get there we crossed many electronic gates, we saw the settlers walking in the old city as if it is their own city. It is so unfair to us Palestinians, they stole our city and our lands, and we crossed electronic gates, while they walk freely in our lands. How come?

Allowing illegal settlements to redefine Palestinian neighborhoods and communities is only one of many strategies implemented by the Israeli government to fragment geographic self. One male participant discusses the Israeli use of checkpoints as another strategy,

Checkpoints are all over Palestine to represent this occupation... There are checkpoints where people wait hours to pass, if there is no checkpoint it will take a few minutes... These checkpoints should be removed because this is our land and no one has the right to govern.

The living conditions of Palestinians under Israeli occupation during Abbas leadership have not resulted in statehood. On the contrary, Israel continues to expand settlements and confiscate land and most importantly, reform Area $\mathrm{C}$ in the West Bank, where the majority of water and mineral reserves are located (Selby 2013). This practice of portioning out land with the Israeli control of roads and resources in the West Bank is congruent to Abbas' inability to achieve a Palestinian statehood.

\section{Abbas era expressive self}

Palestinians use many different tools of expression such as poetry, paintings, and other forms of art and media to not only express themselves, but also to express resistance against occupation. Marshall (2013) discusses how beauty and aesthetics in relation to nationality and religion are strongly expressed throughout Palestinian children's lives, despite the dominant view of them as mere passive victims of trauma. However, within the Ababs era, certain forms of public expression are restricted. Shortly after its formation, the PA began to limit media outlets in Palestine by means of threatening editors, shutting down newspapers and arresting journalists who criticized them, leading many to question their intentions (Jamal 2000). Additionally, the PA's initial support for a popular satirical TV show, Watan Ala Watar, diminished upon the PA becoming fearful of a civilian uprising. The show was banned from the network in 2011, based on a ruling dating back to before occupation which stated the government could take legal action for 'slander against the authority' (Sienkiewicz 2012). A government's effort to control the media within their country can be seen as an attempt to manipulate its citizens and control their livelihood and political aspirations (Cavatorta \& Elgie 2010).

The Abbas era expressive self also involves simple, daily behaviors such as wearing certain clothing pieces, as a female participant wrote, "Today we had a celebration of Al-Nakba Anniversary, and we all agreed to wear the Palestinian's Hattah and we hold banners which we hung later on the school walls. And we dressed shirts inscribed with the right of return."

Children integrated numerous forms of expression into their daily routines, especially in relation to Al-Nakba, and Al-Naksa, which are observed annually and involve multiple forms of expression for the Palestinian children, including costumes or fashion, poems, and banners, as another female participant wrote,

Al-Nakba celebration was a beautiful day... I participated in the Folk costume part, my father took me to a village and took a flaha [embroidered], dress and put rings and wristbands... There were many parts, and the final one was a poem by me, the poem title was (I'm with terrorism) by Nizar Qabanni, I read it loudly. Everyone said that it was an excellent poem.

'Poetry of resistance' is one method that Palestinians use to "address concepts of history, nationalism, and the role of literature in the liberation struggle" (Mir 2013, 110). Despite Abbas' and the PA's attempt to control various aspects of expression, Palestinians still found a way to articulate the expressive self. The reality of the Abbas era expressive self differs for every Palestinian, but their creativity is commonly linked by their experiences of struggle. Children valued the various facets of 
the expressive self, as it allowed them a chance to creatively demonstrate their opposition to occupation and Abbas. The sentiment is that Abbas is allowing facets of the expressive self, as long it is complying with political discourse.

\section{Theme two: the other}

Part of national identity encompasses the construction of the other. For Palestinians, the other is primarily founded on Zionism and Israeli occupation, yet, the other is constructed with some dimensions that disrupt the merely oppressive image of the other. Hence, during the Abbas era, five dimensions of the other emerged as a result of the analysis process: (1) Abbas era oppressive other, (2) Abbas era scattered other, (3) Abbas era religious other, (4) Abbas era allying other as well as one new dimension, and (5) Abbas era oppressive support other.

\section{Abbas era oppressive other}

Oppressive practices against Palestinians are embedded within Zionism, which initiated the fragmentation of the Palestinian community. In 1917, the Balfour Declaration gave the Zionist movement the right to establish a Jewish homeland in Palestine (Beinin \& Hajjar 2014). The participants emphasize such history due to its impact on their contemporary daily lives. Children maintain memories associated with oppression and exploitation brought on by historical colonization and political conflict (Habashi 2013). Oppression is a part of Palestinian children's lives, as they are both witnesses and targets of Israeli occupation. The oppressive other within the Abbas era is emphasized within the relations of continuous Israeli occupation and unjust practices against the Palestinian people. This was especially apparent in the participant's recollections of the Israeli army's invasion of the Gaza Strip in 2008, where around 1,400 Palestinian lives were lost, only a small portion of which were combatants (United Nations 2009).

In many of the journal entries, the participants documented their views of Israel's oppressive practices and injustices, as well as their own lack of ability to help during the Israeli 22 day offensive attack on the Gaza strip, in which the Israeli army attacked Gaza, claiming that an existing ceasefire had been violated. The attack involved massive airstrikes and ground assaults, which targeted civilians including women and children (Hussain 2010). A female participant provided insight on the subject in her journal entry:

It is the sixth day of the continued holocaust in Gaza, the martyrs' number reached 400 and 2,000 injured this morning, who accepts that? These Humanitarian crimes, they wildly kill people... Until now the air raids continued because they will stop it when Hamas stop launching. There is no comparison between our rockets and their destructive rockets, they damaged even the mosques, whatever they do to us we will survive.

Another journal entry from a female participant expressed fear regarding the conflict and political involvement or lack thereof on Mahmoud Abbas' part to achieve peace, and the violation of human rights for Palestinians and its relation to terrorism, stating:

This is a war, no this isn't a war, this is a massacre because the two forces in the war should be balanced, but here its children massacre, and how this could happen? Where is the human rights? How come 13 children were killed in two days and most of them under the age of 3 and what is their fault to deserve this? Where are the human rights when 120 persons were killed in 3 days and they are women, children, and elderly. And when anyone speaks aloud they said Palestinians are terrorists, what about Israel? Is this is the peace and freedom which Condoleezza Rice, Berez, and Abbas are talking about? Abbas is always silent against what happened, he sees his people died and say nothing, is this our elected president...How the Palestinian children will call for peace while Israel is killing their families in front of them. Of course they will be terrorists.

Abbas' political goal is to strike a peace deal with Israel, thus attaining statehood for Palestinians. However, both Abbas leadership and the Oslo Accord have failed to achieve this goal. The political situation has not changed, on the contrary, Israeli occupation continues and settlements have doubled (Shafir 2007). 


\section{Abbas era scattered other}

The scattered other is ingrained in the existence of Jewish people from around the world and their impact on the Palestinian community, which began in the early $20^{\text {th }}$ century alongside the Zionist movement and the creation of Israel. In the Abbas era, the scattered other is largely associated with Israeli settlers in the West Bank. Prior to 1948, Jewish communities were integrated throughout different European countries, such as France and Poland, as well as other parts of the world such as Russia, and some even within Palestine, where Arabs and Jews coexisted in peace (Ben-Bassat 2009).

Palestinian children acknowledged that Jewish communities were rejected and persecuted in other countries (Habashi 2008). Furthermore, they understood the merit of solving the issue of discrimination for Jewish communities in Europe in relation to immigration to Palestine. However, the participants indicated that the scattered other presented a challenge to the Palestinian community's existence, because as Jewish communities began to colonize Palestine in the early $20^{\text {th }}$ century, their goal of creating an Israeli state was conflicting with the Palestinian community's aspiration for a nation-state. Although before the creation of Israel Jewish and Palestinian communities existed side by side, the narrative has changed. The expansion of Israeli/Jewish immigration is associated with oppression and colonization discourse, as one journal entry documented the Jewish settlers attacks on her family, "Settlers attacked the old city of Hebron, Tal Al-Rmedeh, and Alshalalah Street. They attacked the old houses a few days ago, but this attack was the wildest because they planned for it. They attacked Tal Al-Rmeded where my grandpa lives."

Israel has expanded settlements in the West Bank in an attempt to alter future borders. Settlers are controlling roads natural resources, and expelling Palestinian communities (Selby 2013). Settler aggression is supported by the Israeli government not only in military terms, but also in terms of political power, in which settlement blocks have a majority in the Israeli parliament (Sasley \& Sucharov 2011).

\section{Abbas era religious other}

The children's narratives demonstrate that they factor in historical aspects of religion when constructing the other. The fact that Palestine is a holy place for the three Abrahamic religions was recognized and emphasized. Indigenous Palestinian people never failed to recognize that their own national identity was not based on religion, but rather was pluralistic (Khouri 2018). However, when religion became entangled in the politics, change began to occur.

The children in their journal entries expressed concern that Islam was threatened by the Israeli government. Cook (2018) argues that the Israeli government's goal is to Judaize specific areas of Jerusalem by passing laws into effect that prevent Palestinians full access to areas of East Jerusalem. Fields (2010) explains that Israel aims to 'unmake' Palestine by changing the ethno religious character and identity of the land. It has been a work in progress to control the religious narrative in the holy land by changing some religious and cultural sites, and denying access to such sites to Muslims and Christians, referencing the Bible for justification (Khouri 2018). For example, within the al-Haram alSharif compound in the Old City (known as the Temple Mount to Jews), there is the sacred al-Aqsa Mosque and the Dome of the Rock, as well as what Jews believe to be the Second Jewish Temple (Larkin \& Dumper 2012). The Israeli government has been aggressively digging a tunnel from beneath homes in Arab East Jerusalem neighborhoods and beneath the Dome of the Rock, under the false premise that it was the same holy site known as the city of David in biblical times, in hopes of building a Bible-themed tourist park (Buchanan 2011). The digging activities are a concern to Palestinians, and are seen as an attempt to weaken the foundation of the Al-Aqsa Mosque and eventually destroy the sacred building, as was conveyed by a male participant, "Al-Aqsa Mosque is First Kiblah and the third holiest place in Islam... I'm wondering why the Israeli's make digging under Al-Aqsa Mosque,why they want to destroy it, why they want to kill our dreams?"

This attack on a significant religious symbol was not necessarily exclusive to Muslims or Islam, as the Palestinian children also recognized the concept of 'judaizing' their narrative, while attacking Christianity at the same time. As Raheb (2002) points out, the Israeli government recognizes Jewish 
Holy Sites under their 1967 Protection of Holy Sites law, but denies preservation of any Christian or Muslim religious sites; and their Law of Return guarantees immediate citizenship to Jewish immigrants of any nationality, but denies that right to native Christians and Muslims forced to flee during alNakba and al-Naksa. A female participant expanded on the idea that Israel is attempting to oust Christianity by sharing a story regarding a local media source,

The announcer of the tenth channel of Israel has offended Jesus by likened him to a vile man. Also the announcer flouted Jesus and his mother Mary. Why they flouted the other religions while we respect them. They insulted our religions, we will not allow this offense. No one can stop them, they insult us and we [are] all paralyzed.

The politicization of Judaism has succeeded in achieving the creation of Israel as well as the continuous attempt to expel both the Muslim and Christian communities, so as to expand the notion of judaizing the region. The progress of such practices entails changing the religious narrative of Palestinian people by means of altering religious sites, which have meaning to both Muslims and Christians, as well as enforcing unfair laws that benefit only Jewish people. The dimension of the religious other is reinforced through the oppression of others' belief systems and controlling the religious narrative.

\section{Abbas era allying other}

The complexity of the allying other is found in the deviation from dominant characteristics of the other category, which recognize the rights of the Palestinian people. This dimension is defined in terms of mutual respect, whereas the Palestinian rights to exist are not neglected. Despite Israel's establishment in 1948 as a result of the Zionist movement, Palestinian children are able to recognize that not all Jewish people are Zionists. The participants were aware that some Jewish individuals stand with the Palestinian cause and do not identify with Israeli oppressive practices. Although, such perspectives were associated with Jews residing outside Israel, as one female participant stated "Jews who are not living here and they're saying this is not our land. These groups are not settlers, and they are living overseas. They do not mix with the Israelis that are killers and terrorists". Not all sects of Judaism supported the Zionist movement, nor the establishment of Israel. One example of such groups are Haredi Jews, who have always opposed both the secular and religious aspects of Zionism (Keren-Kratz 2017). Additionally, Roy (2012) mentions the frustration of Jewish-Americans who are "critical of the Israelistes in Israel" due to their unethical handling of settlements and practices that violate the "moral obligations of Judaism" (ibid., 566).

The allying other results from competing discourses that distinguish between Judaism as a belief system and the politicization of religion that presents an opportunity for the participants to challenge the contemporary meaning of the other. The significance of the allying other is grounded in the Abbas era, the failure of attaining a Palestinian state and continuous Israeli occupation.

\section{Abbas era oppressive supporter other}

Israeli oppression is not sustainable without the political and financial support of the United States. Politically, the U.S. has shown support in favor of Israeli in various ways. One example of this is the fact that the U.S. fails to call Israeli settlements illegal, instead only referring to them as illegitimate (Siniver 2012). The Abbas era oppressive supporter other focuses on U.S. economic aid to Israel in terms of military operations that involve billions of dollars in grants each year, which does not include money used to support the Israeli military received through Foreign Military Financing (Berrigan 2009). One male participant discussed the U.S. involvement, or lack thereof in reference to the Israeli invasion of Gaza in 2008 stating, "America which calls itself the peacekeeper is silent too. They are with Israel."

Palestinian children recognize the role that their own president plays in relation to American politics. As was reflected on by a male participant who narrated President Bush's arrival to Palestine in conjunction with President Abbas' involvement with the visit,

Bush arrives to Tel Aviv, Bush is the USA president. He is the killer of Iraqi and Palestinian children... the mastermind of Israel to commit crimes against us. I'm so confused and stressed today, since his three planes are more than Bethlehem and it brings soldiers, cars, and guard dogs... He will visit 
our president too, how Abbas could welcome him while he is the responsible for all the crimes which happened to us. He will welcome the killer. Abbas said this will help our country, how come?

There has been seemingly consistent support from the American government to Israel regardless of leadership, as various administrations have stuck to strategic plans that place Israel's security above all other considerations (Hamdi 2018). The children had hope for the next U.S. president, as they discussed the 2008 United States presidential election,

Obama and Hillary Clinton are competing for presidency. The whole world is awaiting this election because the whole world is under America's control, what happens in America happens to the whole world, politically or economic. It governs the world financially, politically, and all countries just listen to its orders and decisions... We urge the new president to care much about the Palestinian case and to have a solution, which has all the Palestinians rights.

The election of President Obama did not yield the desired changes for Palestinians, as Israel continues its negligence of US-sponsored agreements by "continuation of settlement building and its violation of the sacred Muslim shrines in Palestine" without any retribution from the United States (Hamdi 2018 , 252). Despite the fact that the U.S. claims to be neutral in the Palestinian/Israeli conflict and has the potential to be a major asset for peacemaking, their policies have always tended to favor Israel (Hamdi 2018). The participants are aware that U.S. policies towards Israel have the potential to alter oppressive practices. In the Abbas era, however, such change has not occurred.

\section{Conclusion}

National identity is not static, as is evident in the uniqueness of Palestinian children's construction of national identity that was expressed during the leadership of Abbas. It significantly demonstrated the political friction between Hamas and the Fatah led PA, and the resulting relationship and interactions with Israel. This raises the issue of whether these realities will shape the historical interpretation of being a Palestinian for coming generations, since the fragmentation is increasing, not only for Palestinians prior to 1948, but also now for Palestinians within the West Bank and Gaza Strip. By examining the subcategories of the self and other, and the nuances that emerge within them, it becomes clear that national identity is not static, but rather something that evolves as a result of both history and local political factors.

Children are actively contributing to the formation of national identity, while reflecting on occurrences within their political eras, in this case, the Abbas era. The consistent element found in Palestinian national identity over time is associated with Israeli colonization. Though the perception towards it has evolved, it continues to be associated with oppressive practices, with the exception of distinguishing between individuals who support Israeli oppression regardless of their religious affiliation, and with individuals who believe in Judaism but do not endorse Israeli occupation. The inherent association with the self correlates with the geopolitics of history, resistance and pride, excluding the traitor self, in which the participants indicate a lack of trust and commitment to the Palestinian cause, as demonstrated by Abbas leadership.

The inherent association with the other is enforced by the continuous reality of occupation and the lack of Abbas to deliver a plausible political solution. Children's ability to construct the other with such details reflects not only their ability to observe and understand global politics, but also the local discourse that conveys the complexity of the other. Palestinian children's national identity demythized the trust of people and leadership under oppression. Lack of trust in the leadership was reflected in the construction of the self, as well as the assumption that the common interest of the people might not be in allegiance with the political agenda of the Palestinian Authority.

Under the Abbas era, the dimensions of national identity demonstrate a lack of progress. Although one might assume that the implementation of the Palestinian Authority would reflect Palestinian sovereignty, this is far from reality. Indeed, Palestinian children's national identity provided insight to the lack of cohesiveness of Abbas leadership, and Palestinians' experiences within relations with Israeli oppression and more importantly the division in between Hamas and PA and the West Bank and Gaza Strip. Hilal (2010) argued that Hamas and Fatah must truly reconcile in order to resolve 
internal conflict and reform legislative institutions. However, both Hamas and Fatah believe they will lose politically, thus a reconciliation will not be easy. Children's national identity provides a glance into the political future, as this generation must not only resist Israeli oppression, but also oppression from their Palestinian leadership and its political manifestation.

\section{Acknowledgements}

I'd like to thank Chelsea D. Hammett of The University of Oklahoma for her constructive feedback, consistent edits and overall dedication to this manuscript.

\section{References}

Anderson, B. (2006) Imagined Communities: Reflections on the Origin and Spread of Nationalism. Verso Books, New York.

Andoni, L. (1997) Redefining Oslo: negotiating the Hebron protocol. Journal of Palestine Studies 26(3) 17-30. https://doi.org/10.2307/2538153

Baskin, G. (2001) The Jerusalem problem: the search for solutions. Palestine-Israel Journal of Politics, Economics, and Culture 8(1) 6.

Baumgarten, H. (2005) The three faces/phases of Palestinian nationalism, 1948-2005. Journal of Palestine Studies 34(4) 25-48. https://doi.org/10.1525/jps.2005.34.4.25

Beinin, J. \& Hajjar, L. (2014) Palestine, Israel and the Arab-Israeli conflict: a primer. Middle East Report. https://web.stanford.edu/group/sper/images/Palestine-Israel_Primer_MERIP.pdf

Ben-Bassat, Y. (2009) Proto-Zionist-Arab encounters in late nineteenth-century Palestine: socioregional dimensions. Journal of Palestine Studies 38(2) 42-63. https://doi.org/10.1525/ jps.2009.38.2.42

Berrigan, F. (2009) Made in the U.S.A.: American military aid to Israel. Journal of Palestine Studies 38(3) 6-21. https://doi.org/10.1525/jps.2009.XXXVIII.3.6

Buchanan, G. (2011) Misunderstandings about Jerusalem's Temple Mount. The Washington Report on Middle East Affairs 30(6) 1664.

Cavatorta, F. \& Elgie, R. (2010) The impact of semi-presidentialism on governance in the Palestinian Authority. Parliamentary Affairs 63(1) 22-40. https://doi.org/10.1093/pa/gsp028

Cook, J. (2018) Israel amps up ethnic cleansing in order to further judaize Jerusalem. The Washington Report on Middle East Affairs 37(1) 14-16.

Dabed, E. (2010) Decrypting the Palestinian political crisis: old strategies against new enemies: Chile 1970-73, Palestine 2006-09. Arab Studies Quarterly 32(2) 73-91.

Dolphin, R. \& Usher, G. (2006) The West Bank Wall: Unmaking Palestine. Pluto Press, London.

Elgindy, K. (2011) Palestine goes to the UN: understanding the new statehood strategy. Foreign Affairs 90(5) 102-113.

Farsakh, L. (2011) The one-state solution and the Israeli-Palestinian conflict: Palestinian challenges and prospects. The Middle East Journal 65(1) 55-71. https://doi.org/10.3751/65.1.13

Fields, G. (2010) Landscaping Palestine: reflections of enclosure in a historical mirror. International Journal of Middle East Studies 42(1) 63-82. https://doi.org/10.1017/S0020743809990821

Ghanem, A. (2013) Palestinian nationalism: an overview. Israel Studies 18(2) 11-29. https://doi. org/10.2979/israelstudies.18.2.11

Giacaman, R., Khatib, R., Shabaneh, L., Ramlawi, A., Sabri, B. Sabatinelli, G., Khawaja, M. \& Laurance, T. (2009) Health status and health services in the occupied Palestinian territory. The Lancet 373(9666) 837-849. https://doi.org/10.1016/S0140-6736(09)60107-0

Gilhotra, J. (1995) The concept of "self". The Australian and New Zealand Journal of Psychiatry 29(4) 598-603. https://doi.org/10.3109/00048679509064973

Habashi, J. (2005) Creating indigenous discourse: history, power, and imperialism in academia, Palestinian Case. Qualitative Inquiry 11(5) 771-788. https://doi.org/10.1177/1077800405276809

Habashi, J. (2008) Palestinian children crafting national identity. Childhood 15(1) 12-29. https://doi. org/10.1177/0907568207086833

Habashi, J. (2013) Children's religious agency: conceptualising Islamic idioms of resistance. Area 45(2) 155-161. https://doi.org/10.1111/j.1475-4762.2012.01126.x

Habashi, J. (2017) Political Socialization of Youth: A Palestinian Case Study. Palgrave Macmillan, New York. https://doi.org/10.1057/978-1-137-47523-7 
Halabi, U. (2009) The legal status and rights of the Palestinians displaced as a result of the June 1967 war. Palestine - Israel Journal of Politics, Economics, and Culture 15/16(4) 54-64.

Hall, S. (1997) The spectacle of the 'other'. In Hall, S. (ed.) Representation: Cultural Representations and Signifying Practices, 223-290. The Open University, Milton Keynes.

Hamdi, O. (2018) American foreign policy toward the Arab-Israeli conflict: strategic transformations. Insight Turkey 20(2) 251. https://doi.org/10.25253/99.2018202.12

Hilal, J. (2010) The polarization of the Palestinian political field. Journal of Palestine Studies 39(3) 2439. https://doi.org/10.1525/jps.2010.XXXIX.3.24

Høigilt, J. (2015) Nonviolent mobilization between a rock and a hard place. Journal of Peace Research 52(5) 636-648. https://doi.org/10.1177/0022343315572497

Hopkins, P. \& Pain, R. (2007) Geographies of age: thinking relationally. Area 39(3) 287-294. https:// doi.org/10.1111/j.1475-4762.2007.00750.x

Hussain, N. (2010) Israel's Gaza invasion geopolitical changes and regional security implications. Policy Perspectives 7(1) 121-134.

Jamal, A. (2000) State-formation, the media and the prospects of democracy in Palestine. Media, Culture \& Society 22(4) 497-505. https://doi.org/10.1177/016344300022004007

Jarbawi, A. \& Pearlman, W. (2007) Struggle in a post-charisma transition: rethinking Palestinian politics after Arafat. Journal of Palestine Studies 36(4) 6-21. https://doi.org/10.1525/jps.2007.36.4.6

Kattan, V. (2005) The nationality of denationalized Palestinians. Nordic Journal of International Law 74(1) 67-102.

Kaufman, E. (2011) Palestinian non-violent action - a strategy to be taken seriously. Palestine - Israel Journal of Politics, Economics, and Culture 17(3/4) 166-169.

Khouri, R. (2018) Palestinians deserve and will get a more serious leadership. The Washington Report on Middle East Affairs 37(2) 16-17.

Kurtzer, D. (2017) Transformational leadership and the prospects for peace. Palestine - Israel Journal of Politics, Economics, and Culture 22(2/3) 7-14.

Larkin, C. \& Dumper, M. (2012) In defense of Al-Aqsa: the Islamic movement inside Israel and the battle for Jerusalem. The Middle East Journal 66(1) 31-52. https://doi.org/10.3751/66.1.12

Løvlie, F. (2014) Questioning the secular-religious cleavage in Palestinian politics: comparing Fatah and Hamas. Politics and Religion 7(1) 100-121. https://doi.org/10.1017/S1755048313000527

Marshall, D. J. (2013) 'All the beautiful things': trauma, aesthetics and the politics of Palestinian childhood. Space and Polity 17(1) 53-73. http://doi.org/10.1080/13562576.2013.780713

Milton-Edwards, B. (2008) The ascendance of political Islam: Hamas and consolidation in the Gaza Strip. Third World Quarterly 29(8) 1585-1599. https://doi.org/10.1080/01436590802528739

Mir, S. (2013) Palestinian literature: occupation and exile. Arab Studies Quarterly 35(2) 110-129. https://doi.org/10.13169/arabstudquar.35.2.0110

Nassar, J. (1997) The culture of resistance: the 1967 war in the context of the Palestinian struggle. Arab Studies Quarterly 19(3) 77-98.

Omar, A. (2017) Al-Aqsa Mosque's incident in July 2017: affirming the policy of deterrence. Insight Turkey 19(3) 69-82. https://doi.org/10.25253/99.2017193.05

Podeh, E. (2011) The symbolism of the Arab flag in modern Arab states: between commonality and uniqueness. Nations and Nationalism 17(2) 419-442. https://doi. org/10.1111/j.1469-8129.2010.00475.x

Roy, S. (2012) Culturally unconscious. International Communication Gazette 74(6) 556-570. https://doi. org/10.1177/1748048512454823

Sasley, B., \& Sucharov, M. (2011) Resettling the West Bank settlers. International Journal 66(4) 9991017. https://doi.org/10.1177/002070201106600423

Schenker, H. (2008) 2009 - A year of new opportunities. Palestine - Israel Journal of Politics, Economics, and Culture 15(3) 3-4.

Selby, J. (2013) Cooperation, domination and colonisation: the Israeli-Palestinian joint water committee. Water Alternatives 6(1) 1-24.

Shafir, G. (2007) Israeli-Palestinian peacemaking and its discontents. Contexts 6(4) 46-51. https://doi. org/10.1525/ctx.2007.6.4.46

Shlaim, A. (2009) How Israel brought Gaza to the brink of humanitarian catastrophe. The Guardian 06.01.2009 <https://www.theguardian.com/world/2009/jan/07/gaza-israel-palestine>. 19.03.2018.

Sienkiewicz, M. (2012) Out of control: Palestinian news satire and government power in the age of social media. Popular Communication 10(1-2) 106. https://doi.org/10.1080/15405702.2012.638575 
Siniver, A. (2012) Arbitrating the Israeli-Palestinian territorial dispute. International Politics 49(1) 117129. https://doi.org/10.1057/ip.2011.30

Slater, J. (2001) What went wrong? The collapse of the Israeli-Palestinian peace process. Political Science Quarterly 116(2) 171-199. https://doi.org/10.2307/798058

Tadros, V. (2017) The persistence of the right of return. Politics, Philosophy \& Economics 16(4) 375399. https://doi.org/10.1177/1470594X17736265

Tartir, A. (2017) Criminalizing resistance: the cases of Balata and Jenin refugee camps. Journal of Palestine Studies 46(2) 7-22. https://doi.org/10.1525/jps.2017.46.2.7

Tawil-Souri, H. (2012) Uneven borders, coloured (im) mobilities: ID cards in Palestine/lsrael. Geopolitics 17(1) 153. https://doi.org/10.1080/14650045.2011.562944

Tuastad, D. (2013) HamasPLO relations before and after the Arab Spring. Middle East Policy 20(3) 86-98. https://doi.org/10.1111/mepo.12035

Tyler, A. (2011) Encounters with Zionism: a ripened vision for peacemaking? International Journal on World Peace 28(1) 67-84.

United Nations (2009) Human Rights in Palestine and Other Occupied Territories. Report of the United Nations Fact-Finding Mission on the Gaza Conflict. A/HRC/12/48. <https://www.un.org/ ruleoflaw/files/UNFFMGC_Report.pdf>

Usher, G. (2006) The democratic resistance: Hamas, Fatah, and the Palestinian election. Journal of Palestine Studies 35(3) 20-36. https://doi.org/10.1525/jps.2006.35.3.20

Venn, C. \& Featherstone, M. (2006) Modernity. Theory, Culture \& Society 23(2-3) 457-465. https://doi. org/10.1177/0263276406064829

Zelnick, R. (2010) Shifting sands: why peace talks might just work. World Affairs 173(4) 23-32. 